\title{
Dance with Petrushka: The Ballets Russes, Russia, and Modernity
}

\author{
Mengyang Wu \\ Beijing Dance Academy, Beijing, China \\ Email: cis2018@foxmail.com
}

How to cite this paper: Wu, M.Y. (2019) Dance with Petrushka: The Ballets Russes, Russia, and Modernity. Open Journal of Social Sciences, 7, 81-96.

https://doi.org/10.4236/jss.2019.78007

Received: May 13, 2019

Accepted: August 10, 2019

Published: August 13, 2019

Copyright $\odot 2019$ by author(s) and Scientific Research Publishing Inc. This work is licensed under the Creative Commons Attribution-NonCommercial International License (CC BY-NC 4.0). http://creativecommons.org/licenses/by-nc/4.0/ (c) (i) \&) Open Access

\begin{abstract}
This paper utilizes the historical-comparative research method and the literature research method to carefully examine Petrushka, one of the most highly influential ballets during the $20^{\text {th }}$ century. By analyzing the expression of the ballet, the literature infusion and reconstruction, modernism tendencies in music, tableau design, and aesthetic shifts based on historical cultural changes, the socioeconomic influences on art creation will further illustrate how the experience of art can reflect the changes due to modernity from a unique perspective. Therefore, the argument presented here is that modernity in Russia has not only been associated with a view of history centered on Europe or the West, but it is also related to transformations due to modernity in economies and geopolitics worldwide, which has caused multiple infusions, conflicts, and collisions in culture.
\end{abstract}

\section{Keywords}

Diaghilev, Petrushka, Ballet Russes, Russianism, Modernism, Modernity

\section{Introduction}

The decline of classical ballet in Western Europe provided the impetus for Diaghilev and his Ballets Russes tour. We can reasonably say it was Diaghilev and his Ballets Russes that put Russia at the forefront of the international avant-garde during the 1910s-1920s. Various publications have investigated this phenomenon, and the literature is diverse, including memoirs, biographies, and specialized studies of choreography, stage design, costumes, and fashion, as well as some broader attempts at interpretation. Lynn Garafola, for example, wrote a biography of Diaghilev as well as several articles about him, which covered not only Diaghilev but also the artists in his circle. In particular, in the essay "The Making of Ballet Modernism," Garafola examined the influence of futurism, 
neoprimitivism, the pre-Romantic artistic heritage of Latinity, and the world marketplace on modern ballet [1]. Hanna Järvinen, meanwhile, discussed the Russian invasion from historical and geographical perspectives and analyzed the presence of primitivism, realism, barbarism, and modernism in repertories [2]. In addition, Stanley J. Rabinowitz published an article called "From the Other Shore: Russian Comment on Diaghilev's Ballets Russes." Another article by Järvinen, titled "The Russian Barnum': Russian Opinions on Diaghilev's Ballets Russes," collects, synthesizes, and analyzes commentary by various Russian and Western European critics on Diaghilev and his Ballets Russes [3] [4]. Regarding aesthetic aspects, Annabel Rutherford and Frank Kermode have examined the influence of literature on Diaghilev's work [5] [6]. Charles S. Mayer, meanwhile, investigated design inspirations from Leon Bakst and Mir Iskusstva [7].

Diaghilev's relationship to modernity has been studied in terms of various aspects, including choreography, tableau, costume, fashion, cosmopolitanism, and nationalism, among others. Few studies, however, have focused on a specific work, with almost no research taking Petrushka as a starting point. The present study, therefore, takes Petrushka-an influential and representative work of $20^{\text {th }}$ century ballet-as a point of entry to analyze cultural integration and conflict during the transformation period of Russian modernity in terms of the changes observed in dance works of the time. This article extends the literature on ballet analysis and cultural studies in various ways. First, it provides an in-depth supplement to prior discussions of modernity in Diaghilev and his ballet company. Furthermore, the analysis of Petrushka reveals changes in existing dance forms, the meanings of the works, and historical and cultural backgrounds, as well as the deeper philosophical, economic, and social aspects of modernity that influenced the understanding of beauty. By revealing the aspects of judgment and doubt in the dance works that knowledge alone cannot provide, this study broadens the field for analyzing both Russian modernity and specific dance works from an ontological perspective.

\section{Method}

Taking Petrushka as the research object, this analysis will use historical comparison and literature research to analyzes the influence and infiltration of artistic works from Russia's period of modern transformation in terms of multiple cultural aspects.

As a highly varied process, to understand modernity and evaluate the conceptual transformation behind it, we need to trace the time sequence before and after the phenomenon. By examining differences in the choreography, music, tableaux, and script of Petrushka and putting it in its historical context, we can obtain a unique genre identification and clarify the characteristics of the work. Thus far, this paper has situated Petrushka in its geopolitical and socioeconomic contexts. In addition, economic, political, and social changes can be examined to investigate mutual influence in artistic creation. The method of historical com- 
parison has been widely used in dance research. Järvinen, for example, used historical comparison to show how Ballets Russes became a company that performed Russianness, culminating in barbaric novelty and orientalism [2]. That study examined the social atmosphere of the Russian invasion to explain how separate development in Western European and Russian art gave rise to different critical views of Ballets Russes. It also compared old and new ballet from Gorinsky in Russia to Dalcroze's eurhythmics in Germany; this diachronic approach to technical factors provides a clear view of ballet development. In addition, Järvinen compared Russian realism and modernism with French barbarism using horizontal synchronic comparison and diachronic regional comparison, providing abundant entry points to clearly represent the intricacies of the first-hand materials.

The present article considers from a unique perspective how the experience of art can reflect the changes arising from modernity. Since modernity is a continually shifting concept representing transformations over the past $300-400$ years, it should be investigated by considering the characteristics and dynamic interactions of different countries in different historical periods. By using historical comparison, we can consider all of the elements of genre and style in terms of their ontological aspects, including foot positioning, diatonic modalities, narrative metaphors, and stage devices. In this way, we can comprehensively analyze the influence and penetration of historical, cultural, economic, and social factors, among others.

\section{Dance with Petrushka in the Transformation of Russian Modernity}

Understanding a specific event or movement in the history of art requires a constant shift of perspective between the diachronic and synchronic history contexts. The emergence of cultural modernism affected almost every domain of art, which in its turn generated diversified styles and genres. In Russia, like the rest of the world, modernism and modernity are related but not the same. Since the history of the Ballets Russes speaks to both, the differences and interactions between them need to be first addressed. Modernism here stands for explicit, programmatic, and fundamental challenges to existing conventions. This rejection of what was perceived and decried as old went along with a demand for radical innovation and experimentation. This disposition affected almost every branch of the arts and literature. Modernity, however, is a different, broader, even protean concept. In particular, modernity is an idea that has been undergoing significant changes. It has traditionally been associated with a view of history centered on Europe or the West, and contemporary discussions of modernity now often consider the existence of multiple modernities. In this paper, modernity points to the complex interactions between Russia and various parts of Europe that ranged across diverse domains from techniques via political ideas to culture. This interaction was dynamic and persistent. This was not the only factor in 
shaping Russian history over the last 300 - 400 years, but its influence was crucial.

\subsection{New Ballet Presented in Petrushka}

The story of Petrushka originally came from a Russia folk fair, Shrovetide Fair (Maslenitsa), during the 1830s.

The Charlatan brought three puppets, Petrushka, Ballerina, and the Moor (black) to an open plaza in St. Petersburg for Carnevale performance. Backstage, Petrushka admired the Ballerina and couldn't take attention off her during the performance, however, the Ballerina refused him. In the Moor's exotic room the Ballerina flirted with the Moor, which agitated Petrushka. Outraged and angry, he broke into the room and chased the ballerina insanely. Seeing Petrushka expelled by the Moor, the Ballerina jumped into Moors embrace apathetically and happily. The jealous and cowered Petrushka was killed by the Moor eventually. The charlatan lied to the police by showing Petrushka was just a puppet. The crowd dispersed, Petrushka emerged on the ruff of the theater, weighing his fist against the moonlight and swore to revenge, leaving the confused audience wondering what is reality.

Created jointly by Igor Stravinsky, Leon Benois, and Michael Fokine, Petrushka probably best represents the collective creation method of the Ballet Russes. In Petrushka, Fokine began his first exploration to create psychologically sophisticated roles that combined realism and the fantasized characteristics of Russia folktales [9], making this his first foray into choreographing from the inner world of the character. The Moor uses the en dehors (ballet terminology: open outward) gesture to depict an outgoing and arrogant charlatan, whereas Petrushka uses the en dedans (ballet terminology: adduction) pose, gestures, and movements to express the character's pity oppression and hopeless efforts to achieve personal dignity. Nijinsky's splendid performance infused the role with an imposing soul, particularly the practice of turning legs inward gave Petrushka a constringent space to move himself, this allowed him to express the depression and the struggle of dualistic characters [8], which is internal opposition to himself. By employing the en dedans foot and positions, Fokine successfully conveyed the introverted and pusillanimous image of the protagonist.

Furthermore, as a chief choreographer of the Imperial Theatre, Fokine was fully aware that the strict constraints of the old ballet had already descended to a flaunting of virtuosity of famous ballerinas, which eventually became acrobatics without any inspiration of the audience's aesthetic [1]. In Petrushka, Fokinecreated the poetic and imaginative gestures from nature to illustrate the inner emotion. The picturesque dancing and pure delightful movements represented by the flexible, fluid, and spontaneous poses, gestures, and actions made the work never fail to retain its graceful classic spirit. At the same time, the attention to dramatic climax, personal conflict, and psychological struggle infused Fokine's ballet with a sense of unutterable powerful expressiveness [3]. 
To address why the choreographer in the late $20^{\text {th }}$ century began to draw their attention to the human psychology spectrum, it would be necessary to discuss how the transformation of modernity remolds the ideology of human beings. At the beginning of the $20^{\text {th }}$ century, Freud and the psychology theory of his followers authentically gave our human history the first shot to recognize the governance of human action motivated by mental activities [9]. To illustrate the understanding and consciousness of a human being's inner world, Fokine exploited body language to portray human feelings instead of showing the fantastic technique of the ballerinas. For instance, given that interval cycles appeared to be the basis for musico-dramatic polarity, (In Petrushka, musico-dramatic polarity separating human and imaginary world by representing conflict in diatonic and chromatic harmony.) [10] such an internal level of polarity spontaneously followed the awkward body movements vividly portrayed the inanimate and human spheres of the puppet, which infused the protagonist, Petrushka, with a magic personality. Fokine focused on displaying the protagonist's mental struggle and characteristic tragedy. Due to the impulse of the rhythms followed by the movement of the dancers, the performance enabled the audience to intensively feel and sympathize.

In the structure of Petrushka, Fokine abandoned the traditional pas de deux in which the danseur always stood behind the danseuse and displayed her. On the contrary, in Petrushka, the danseur for the first time outweighed the danseuse and became the core of the ballet. The narrative of the story went along with the plot clues and climaxes of the psychological contradiction, without the interruptions from the classical ballet paradigm pas de deux, (In the classical ballet, usually abide by the A-B-A model, begin with the pas de deux, then danseur solo and coda, followed after danseuse solo and coda, and finally pas de deux again, in order to show grandiose, extravagant and elegant of the virtuosity ballet could convey.) which was inherited from Petipa.

Culturally and spiritually, Fokine no longer strictly adhered to the aesthetic credo that every movement must begin and end with a return to the five basic positions to match the beauty of geometric mobility in the classical paradigm (five basic positions obeys the basic aesthetic standard of classical ballet "opens outward" principle. One explanation is it derived from the Knights' manner who fight in fencing; they stand sideways to expose themselves as less as possible. The performers of court learn and reform such spirits gesture into basic ballet pose [11]). This was an instant when Duncan relied on techniques from ancient Greece to highlight her Bacchanal revelry in "future dance" and won worldwide recognition. Fokine and Leon Bakst, who were ancient Greek culture experts, had a strong influence on choreographers in the Ballet Russes, and they attempted to infuse the ballet tradition with the movement of ancient Greek vases [7]. Moreover, Fokine also took inspiration from Egyptian embossment and mural painting, especially in Egyptian Night. In Egyptian Night, the elbow was curved and angular patterns of arthrosis were obvious. Duncan or Fokine were both perceived to be extraterritorial from a traditional European perspective, 
and the desire to build up national cultural identities pushed them to explore ancient Greek and Egyptian culture, which were the fundamental origins of western European art.

\subsection{The Fusion of Realism and Symbolism in the Playscript of Petrushka}

In the scenario of Petrushka, the playwright settled the protagonists in the domestic secular life, fleeted out the European gothic forests, prince and princess's fairy tale. Instead of displaying the dramatic climax vividly followed by realistic plot clue, Petrushka draws the audience's attention to the unutterable inner worlds of the characters and depicts the stereotype of "small people." [12] Given the success of Coppelia, [13] the issue of how to create an impressive puppet was crucial for ballet drama. Karsavina did not let the success of the Coppelia overshadow the impressiveness of the character. She created an adorable puppet, no coquetry but likable, and the movements were spontaneously initiated by the puppet and controlled by in vivo invisible lines. She harnessed the internal contradictions of the ballerina and infused menial love and tears in this puppet ballerina, slightly deja du, but arousing a new emotional sympathy.

It is hard to categorize the ethnology of the three protagonists and the function of the role, which increases the novelty of Petrushka's literature and adds difficulties for the accurate interpretation of the work. For instance, none of the plot and story fit the structuralist paradigm of the myth of Levi Strauss [14]. Seemingly the characters could come from anywhere or nowhere, and they reflect the unique complex demographic distribution in Russia.

What should not be ignored is the fact that there was a cultural fusion of the social realism of the 1860s and the symbolism of the 1890s in the process of Russian modernization [2]. Petrushka could be considered a trial of such a combination. The social realism of the 1860 s was an incentive for the great Russian authors Dostoevsky and Tolstoy. For example, they adopted a realistic way to describe contemporary subject matter in a true-to-life manner, showing the pessimistic, vain-industrious, and sympathetic dark side of humanity and society. Such momentum seems a milky away from the idly romantic utopia of ballet. However, the plots of Petrushka are freed from poetic fantasy and magical fortune, and even the love affair between the protagonists never show display any delightful glorious nor the danseuse compromise. In fact, the protagonists even flirt with the black Arab, conveyed by her humble situation.

In contrast, symbolism is not concerned with the outer world, but instead focuses on subjective feelings and metaphors to evoke spiritual exploration. At the end of a scenario using symbolism in the ending scene, the crowd disperses and Petrushka emerges on the ruff of the theater, weighing his fist against the moonlight and swears revenge. This expands the audience's imagination to reverse the previously established world, leaving the audience to wonder where the reality of the setting lies. The audience is made to rethink about their own position in the world. They also have to think about whether reality is what they have always 
believed it to be. Petrushka brings Russian culture back to the dimensions of mysticism, metaphysics, and fantasy, which had been banished by nationalist critics after pressure from the realism movement in Russian art [15].

\subsection{Dance to Russian Rhythms and Melody under Modernism Threshold}

Petrushka is not only significant in Ballet history, but it also represents an essential milestone in music history. In Russia, prior to ballet, music generated a more definite influence on the national art school style establishment. Affected by the nationalist music pioneer Glinka (1804-1857), the famous "the Mighty Handful" or "Russian Five" which consisted of Alexander Borodin (1833-1887), César Cui (1835-1918), Mily Balakirev (1837-1910), Nikolai Rimsky-Korsakov (1844-1908), and Modest Musorgsky (1839-1881) [16] made "Russian music" a completely independent school due to its "freshness, originality, and instrumental craftsmanship." [3] Collecting and absorbing simple Russian traditional folk melody and religious music made "Russian music" fresh to the European audience. In addition, the sophisticated conduct of the western classical musical technique made the music both familiar and exotic to listeners who were stunned by the grandiose virtuosity.

The time during the Ballet Russes Tour, around the 1910s-1920s, was called Stravinsky's "Russian ballet Period." Accompanying The Firebird and the Rite of Spring, Stravinsky boldly explored new music genres and incorporated Russian folk elements. In Petrushka, Stravinsky used interval cycles and diatonic to express the multilateral dimension, giving the music a more extensive modern system. Unlike traditional Russia folk music that builds the melody on a pentatonic scale, [17] like Musorgsky's famous Promenade, Stravinsky used interval cycles to differentiate between the human and fantastic worlds. In the late $19^{\text {th }}$ century, the paintings of Cubism used repeatedly swirling figures and the line of an object against itself to build up dissonant images. Such a cubist technique was pervading for music composers who attempted to use polychords to create musical dissonance in collage, spin, and overlap manners [16]. During the "curses of $P e$ trushka," Stravinsky uses two triads alternatively and interlocks in contrasting instrumental layers, such leading two or triads or seven chords off-center and against each other to create a disharmonic tension in response to the visual impact of dissonant cubism.

Moreover, the chromatic/fantastic being of the third-related kind (whole-tone or octatonic) was used to play off against the fifth relations for human music [10]. The tempo in the traditional Russian manner is noted for its "fast but resolute", usually alternating five- and six-beat measures in an irregular meter. By inheriting this irregular beat, Stravinsky used the strength of the forte of beat to express its primitive and symbolic image. By manipulating independent meters and rhythms to sound at the same time simultaneously, the complexity of the rhythms were eliminating the sentimental and flamboyant topos. 
Stravinsky used a variation of the diatonic modal formations [17] that transcended the traditional concepts of tertian harmonic construction and tonality. Influenced by impressionism music from France, composers in the late $19^{\text {th }}$ century were widely familiar with the whole-tone scale(diatonic) based on equal or symmetrical subdivisions of the octave, and in the whole-tone scale the distance between each pitch is the same. Since there is no significant tonal center, the composer can enter and stop at any note of the scale and make the music float without a tonal anchor. Stravinsky placed these diverse structures into a modern context.

Stravinsky used folk and popular musical material in Petrushka. Instead of modifying and deforming the folk tunes and melodies, he internalized the structure, pitch, rhythm, and tempo of the Russian folk music element. His music draws on authentic folksongs from Rimsky-Korsakov's collection, but they are harmonized and orchestrated in the manner of French Impressionism. The libretto uses motifs from Russian folklore that includes elements taken from impressionism in which the music develops a twisting and swirling sound with no articulated meters or repeating rhythms to lead. His work is not composed in the manner of the languid sensual beauty of impressionistic music, but Stravinsky uses such free impression to build a primitive, nearly barbarian fantasy.

\subsection{The Influence of Mir Iskusstva (The World of Art) on Petrushka}

The exploration of Slavic cultural treasures has never stopped during the last 300 - 400 years. Since Peter the Great transplanted the European culture into Russian, the development of Russia's national identity has corresponded with the need to distinguish itself from the European culture. By seeing art as means of flourishing national consciousness and fostering the national art school to the level that it could wrestle against the Western European invasion, Diaghilev and his Ballet Russes inherited the artistic taste of the art world and further varied stage designs and costumes to expand their exploration and influence.

The tastes of the Mir Iskusstva encompassed the artistic consensus of the masses both distant and steps away from the nobles, aristocrats, and bureaucrats. The rising middle class at the time was relatively small compared to the entire population, including the intellectual, professional, and mercantile classes, and it was the middle class who become the amateur connoisseurs and professional consumers. The living conditions of the peasant class and their social-economic role contributed to the changing of attitudes of lower status groups. The magnitude of the economic environmental changes corresponded to the shift in concepts as economic modernity permeated into the insight of the higher classes. Their focus turned slightly to the new peasant-workers and the daily scene of the ordinary peasant. The motifs and patterns in their daily consumption represented in a new way the mix of cubism, futurism, and impressionism.

At this time, the lower class was typically not a potential audience for ballet, especially in performance ballet art, which originated from royal court enter- 
tainment. The primitive and exotic mystery flavor of this new art form intrigued the artists of Petrushka in the Ballet Russes circle to modify and infuse the European vanguard art concept and traditional Kustar craftsman art into ballet. Their aim was to explore a mixed nationalism expressionistic style whose identity would be both familiar and attracting to a western European audience. For example, in Petrushka, the costumes were decorated with Kustar primitive patterns, and the Moor's room was crowded with dazzling barbarism and oriental lace, embroidery, and colorful decorative design motifs. To satisfy the aesthetic taste of western audiences at that time, the market Petrushka was designed to attract was quite different from the original folk market in Russia. Diaghilev made an effort to display and honor some primitive aboriginal rituals in traditional Russia treasure. What was revealed by the contradictory barbarism and oriental opinion more likely represented the perplexing demographic diversity and intersecting tradition of the Russia unique situation. Petrushka succeeded in absorbing the ideas of foreign modernism while implanting Russian cultural elements into it.

In terms of stage design, "the insufficient market consumption made the Mir Iskusstva produce concepts rather than practical designs," [18] especially in their furniture products. However, such exploration and practice nourished the soil for explorations in stage and costume design in the theater. As Malmstad mentioned in his article "The sets and costumes made by Goncharova and Mikhail Larionov for these ballets, exuberant riffs on peasant grab and motifs from the folk art they had collected for decades, revealed the Neo-Primitivist masters at their colorful decorative best." [19].

Léon Bakst and Alexandre Benois tried to uniform the erudite interest and anti-realistic approach to convey the illusion of fiction. They further developed the assertion of Wagner's Gesamtkunstwerk, [20] and the Mir Iskusstva artists innovated the "scenography" notion. Compared with using pictures to decorate the stage, they took musical, dramatic, and choreography elements into consideration at the beginning of the creation. Each line of pictures implied a dynamic tendency toward the next scene, and the fluidity of the images followed the dramatic plot development. Despite the traditional technique that made costumes reflect the setting and historical context as much as possible, the designers from Mir Iskusstva attempted to construct the costume with physical movements to dance and exteriorize the inherent character of the roles. Moreover, they experimented with space solid geometry possibilities in the stage design. In Petrush$k a$, Benois used an obscure dimension setting in the dolls' room, making the audience look into the scene from a 45 degree angle. Hence, the visual impact directly beat into the heart of the audience, increasing the ability of the audience to empathize with the characters [18].

Assessing the phenomena from a global and transnational perspective, with a vast territory stretching across the continents of Asia, Africa, and Europe, Russia is not only part of the east spatially, but it also bears similarities with the east in a cultural sense for audiences in Western Europe. The diversity of ethnic groups 
in the Russia territory satisfied such an oriental imagination to some degree, whether true or not. The magic, cruelty, barbarism, luxury thrilling, and orgiastic entertainment elements were sufficient to meet the exotic hunting desires of West European audiences. Notwithstanding the Russian comments that criticized the phenomena, it was indecent to the Russian art spirit to flatter the wallets of European audiences. By raising its own money without government financial support, the Ballet Russes often found itself financially struggling, and the company even went bankrupt during the second season of its 1912 tour. The financial situation played a decisive role in ensuring the creation and rehearsal of the dance drama; therefore, audience preference was crucial to whether the dance company would be able to continue to tour in western European theaters.

\subsection{The Cosmopolitan Tendency in the Silver Age Aesthetic Shift}

At the turn of the $20^{\text {th }}$ century, Russia experienced a renaissance in every aspect of art and culture during a period labeled the Silver Age [21] by historians. The significant aesthetic trend of the Silver Age can be found in the symbolism in literature and poetry and, in particular, the aestheticism of the philosophical assertion "Art for Art's Sake" and the highly respected freedom of creativity and individual expression. The artists during the Silver Age broke away from tradition and utilitarian pursuits and opened to and embraced all sorts of art genres and styles. Petrushka is considered to be the best representation of the Silver Age works at that time.

In an essay, "Principles of Art Criticism" by Diaghilev, he claimed that "complex beauty is the highest expression of the personality." [5] Shared by the retrospective spirit formulated by the World of Art, which ceased to be published in 1904, Diaghilev never threw away opportunities to make connections to tradition, including both the strict discipline of classical ballet and the primitive vigorous Slavic dance rituals and ceremonies. When respect to classical ballet, its aesthetic foundation could not be cut from its solid ties to France. Even in the 1990s and before the Great Revolution in 1917, the dominating ballet performances in Russia were still occupied by the Imperial Theater, and the refinement, decorum, elegance, and fluidity aesthetic standards remained the same as during George Noverre's time. The primary audience, which consisted of nobility, bureaucracy, the Tsar, and royalty held onto the appreciation of the frivolity and virtuosity norms inherited from Louis XIV. In addition, the budget provided by the Tsar Imperial political arrangement imperial financial fund could maintain such privilege, it suffered no significant weakness, even though there were an overall decline of classic ballet in Western Europe [22]. Therefore, it is not hard to understand the notion:

"The greatest periods of Russian culture were not those in which it held itself aloof from the West in cultural isolation, but when it welcomed the West and creatively interacted with it. In this interaction, they believed, Russian culture found and expressed its true national and international spirit in a synthesis of 
native and Western elements." [19].

Petrushka accurately highlights this fusion of aesthetic exchanges in contemporary European pluralism. Seemingly, the national identity of every country paradoxically became entranced in the cosmopolitan process, in comparison with other cultures and their re-consecration of self-unique characteristics that gave the native ethnic a panoramic insight into how to comprehensively represent its own identity. It would not be hard to conclude that Diaghilev's elite art circle was making efforts to catch up with this cosmopolitan tendency, and they devoted every chance to foster the a unique Russia aesthetic appearance.

\subsection{The Promotion and Suppression of Art by Social-Economic Changes}

One of the significant cosmopolitan trends in the late $20^{\text {th }}$ century was the rapid economic growth worldwide due to the industrial revolution and capital accumulation. Russia shared the interests of the world economic engine, especially the railway industry. However, the booming economy worsened rural poverty. By the mid-1890s, world grain production had dropped to half of what it was 20 years earlier, which made peasants fall ever further behind their tax and redemption payments. Corresponding with the Emancipation in 1860 and the late $20^{\text {th }}$ century, Russia experienced rapid economic development, especially in the railway industry. Hence, although the differentiation in social-class hierarchical structures did not change significantly, the peasants still dominated the majority of the population, despite ordinary peasants being liberated from the institutional structure of serfdom. The mixing of rural misery and increased social mobility sent the peasants to the cities to find new opportunities for living [23]. The impact of the world capitalist market forced the newly working peasants to abandon their traditional craft living materials for manufactured products for daily consumption. Therefore, Russian social elites tried to save endangered Russian traditional craftsmanship by launching the famous Kustar Art campaign. Patrons from nobility and the court of the Tsar gathered funds and began workshops to systematically train traditional folk in craftsmanship. They did this by not only generating an amount of handiwork crafts for the burgeoning souvenir industry, but also by grafting the motifs, lace, embroidery, and carvings from peasant raw materials to develop merchandise products. However, the action of saving peasant crafts was severely criticized for its paradoxical situation, as it sponsored and formalized traditional national art by systematically training the peasants, and thereby standardizing the crafts. The primitive spirit of national folk art lost its inherent spontaneity and vernacular identity.

Russians who were engaged in commercial businesses are the primary beneficiaries of policies regarding economic growth. They overwhelmingly tended to be loyal to the throne and to be economic as well as cultural nationalists. These people benefited from the recent economic reformation under the Tsar regime. This privileged class (we temporarily call it "middle-class" to distinguish it from the general concept) ebulliently embraced their Slavic heritage. They lavished 
their new wealth on philanthropy and distinctively Russia art and music. The Mir Iskusstva was precisely one of those quintessential art elite circles that practiced these notions. The impresario Sergei Diaghilev exported Russian culture to Paris.

Marxist political economic theory developed the doctrine that "the economic foundation determines the superstructure." Being part of the superstructure in this ideology, even though the scenario of ballet incorporated traditional folklore and secular motifs, the work itself remained exclusive to the upper-class, at least prior to the Russian Revolution in 1917 and the establishment of the Bolshevik regime. Ballet never tried to suit a mass audience. The rising middle class in both intellectual, professional, and mercantile aspects appeared to construct a spontaneous connection with ballet for it shared the same aesthetic ideology as the privileged class. Rapid economic changes especially affected the burgeoning middle classes. The concept of "middle-class" in the historical context of Russia is a complicated terminology and cannot simply be used to articulate common circumstances in Russia. However, the "middle-class" used here is trying to establish a gap between the elite culture that was dominated by the upper class of the court of the Tsar, landowners, and the mass culture. However, another important fact is that "middle-class" in France, even in the synchronic context, was fundamentally different from what it meant in Russia. Therefore, we cannot merely conclude that they shared the same social status and aesthetic ideology. However, the French adored the Ballet Russes enthusiastically. The following is a more accurate picture. The booming economy made Russia's newly wealthy more willing to show their pride by honoring and flourishing their national cultural spirit. Through boldly infusing the primitive and poetic Russian folk elements with the notion of modern art, the artists of Ballet Russes' innovations were strongly attracted to western European culture, who were exploring the modernity of art themselves. Objectively, Diaghilev and his Ballet Russes challenged France's status as a cultural center at that time and pushed Russia to the forefront of the international avant-garde within a decade.

\subsection{Paradoxical Accomplishment: The Reception to the Ballet Russes}

In reviewing criticism from the homeland, it is easy to find that Russian critics were and are still reluctant to comment on what Diaghilev and his Ballet Russes had done for art and ballet. Even many articles that analyze Diaghilev's ballet take a derogatory tone.

Before Petrushka, Russia had been experiencing a momentum of the Realism movement. Gorsky's new ballet in Moscow directly pursued a Realism choreography genre. For Russian critics of realism, the aesthetic tendency of Mir Iskusstva, especially the Romantic utopian choreography style of Fokine, was an escape from the harsh reality of the world. Hence, it is considered conservative and outdated. Compared to Gorsky, Petrushka in an ontological aspect of ballet lacked the bold breakout from Petipa. Nevertheless, should we question its sin- 
cerity in pursuing innovation?

An evaluation of the commercial environment indicates that Petrushka was definitely an export-oriented work, and the Ballet Russes performed a tour during 1909-1912 that was never presented on a Russia indigenous stage. Each one of the performances appeared in foreign Europe. Therefore, each addition of elements in the choreography considered the potential audience. Fokine, Nijinsky, and Karsavina displayed a stunningly adroit virtuosity based on decades of harsh training under the Tsar's systems. In addition, Western European ballet was experiencing a decline in the Romanticism epilogue. Therefore, Petipa's splendid virtuosity technique did not insist on the glorious elements generated from Louis XIV. Petrushka was as grandiose as ballet can be under the strict systematic training taking place behind the stage. It did not consider the cultural background, judging ballet only by the standards of the Russian artistic elite. Might this have put it at risk of cultural chauvinism?

However, the comments from Europedo not provide us with a benchmark for judgment. While Russia's ballet revolution injected vitality and inspiration into the droopy theatrical dance performances of Western Europe, it also intrigued the underlying deep-rooted sense of superiority that Europeans have toward foreigners and their cultures. Praise from Europe has always been associated with "primitive, savage, luxurious, passionate," and other emotional and animalistic characteristics. Such ambivalence makes it hard to provide an objective and fair evaluation in a European commentary [24].

The paradoxical accomplishment of the Ballet Russes profoundly reflects the inevitable dilemma of re-examining local national cultural traditions during the transformation of modernity. It is in this dilemma that we see the struggle of a nation to find its cultural identity.

\section{Conclusions}

To briefly return to the concept of modernity-the starting point of this paper-the term modernus, which first appeared in the fifth century CE, was intended to distinguish between modern Christianity and the earlier pagan Roman society. Modern thus refers to a break with the past, indicating a new sense of time, a distancing from the past, and a look toward the future. As a social and conceptual fact, modernity first appeared in Europe in the $16^{\text {th }}$ century. It is a multidimensional concept that includes political, economic, technological, conceptual, and sociohistorical content, [25] characterized by progressiveness, development-oriented desire, and a belief in ongoing progress. In the modern transformations of the early $20^{\text {th }}$ century, people experienced a kind of futurism-oriented jubilation for continuous progress and scientific innovation. However, this was also accompanied by frustration, depression, anxiety, nihilism, and a sense of absurdity, which cast people into a kind of spiritual wasteland.

The transient, instantaneous, and coincidental features of modern social life penetrated almost all aspects of people's lives. In Paris, cities came to constitute 
the primary spatial field after 300 years of accumulation in the process of modern transformation. Without this emergence of modern European urban social life, Diaghilev could not have operated a touring ballet company that never performed in Russia but won praise and box office success in the birthplace of ballet in the early $20^{\text {th }}$ century. The fragmentation, sensory stimulation, materiality, richness, immediacy, and transience of modern urban life were transformed into unprecedented sensory stimulation, a fragmented sense of life, and transient, ambiguous emotions in ballet works of the time. This phenomenon has generated extensive critical interest, resulting in historical and aesthetic studies of Diaghilev and his Ballets Russes as a whole. This approach has dominated dance research in this area.

This paper, meanwhile, selected a representative work of the Ballets Russes, Petrushka, and explored the political and economic influences on innovations in dance from a cultural perspective. It specifically considered the transformations of modern concepts in the early $20^{\text {th }}$ century in terms of artistic forms, styles, and aesthetics, among other features. Petrushka precisely represents such modern aesthetic shifts. Critical responses to it highlight how such transformations affected the differing views of the Ballets Russes among Western European and native critics. By approaching Petrushka in this way, this paper broadens the horizon for dance research in terms of ontological aspects.

Petrushka's experiments with realist psychodrama and a bold elevation of body language present a successful exploration through music and a nationalistic identity. The bold, avant-garde practices in painting and stage design, as well as cosmopolitan aesthetic concepts, shifted under unique geopolitical economic changes. At first, this reflected a reaction in arts and literature to shifts in Russian modernity. Accordingly, each change in Petrushka represents a significant reformation in modern ballet. Moreover, complex interactions between Russia and other parts of Europe remolded the innovations in Petrushka across diverse domains, from techniques via political ideas to culture. Once the performances of the work were completed, the outside world's understanding of Russia changed. Russian modernity is associated with not only European or Western history but also the broader effects of modernity on the economy and geopolitics, which affected multiple infusions, conflicts, and cultural collisions.

In the development of dance in the $20^{\text {th }}$ century, the radical novelty of modern ballet is highlighted in the lowering of the center of gravity, which results in a lowering of the body hierarchy. Rebelling against the aesthetic principles and technical norms of ballet, the work in this period shows modernity's transformation from rationalism's aesthetic ideal of "sacred", "sublime", and "solemn" to mysterious intuition, creation, and imaginative romanticism, as well as the violence, stubbornness, haste, and pain of the modern. Because of resource limitations, this study did not analyze the body language in Petrushka in-depth in terms of the effort shape notation and motif notation of Laban's choreology and choreutics. These aspects should be discussed in more detail in future research. 


\section{Acknowledgements}

The author expresses her gratitude to Professor Tarik Cyril Amar is an associate professor of Department of History in Columbia University who assisted from the very beginning of the structure and each revised version with crucial comments. In addition, the author also thanks their assistant, Victoria, who provided help with the literature collection and proofread each draft. Moreover, the author thanks Professor Hu from the CIS program who provided advice and instruction in the correct citation and format of this paper.

\section{Conflicts of Interest}

The author declares no conflicts of interest regarding the publication of this paper.

\section{References}

[1] Garafola, L. (1988) The Making of Ballet Modernism. Dance Research Journal, 20, 23-32. https://doi.org/10.2307/1478384

[2] Järvinen, H. (2013) “Great Horizons Flooded with the Alien Light of the Sun": "Le Sacre Du Printemps" in the Russian Context. Dance Research: The Journal of the Society for Dance Research, 31, 1-28. http://www.jstor.org/stable/43282039 https://doi.org/10.3366/drs.2013.0057

[3] Rabinowitz, S.J. (2009) From the Other Shore: Russian Comment on Diaghilev's Ballets Russes. Dance Research: The Journal of the Society for Dance Research, 27, 1-27. http://www.jstor.org/stable/40264005 https://doi.org/10.3366/E0264287509000231

[4] Järvinen, H. (2008) “The Russian Barnum”: Russian Opinions on Diaghilev's Ballets Russes, 1909-1914. Dance Research: The Journal of the Society for Dance Research, 26, 18-41. http://www.jstor.org/stable/40263985 https://doi.org/10.3366/E0264287508000042

[5] Rutherford, A. (2009) The Triumph of the Veiled Dance: The Influence of Oscar Wilde and Aubrey Beardsley on Serge Diaghilev's Creation of the Ballets Russes. Dance Research: The Journal of the Society for Dance Research, 27, 93-107. http://www.jstor.org/stable/40264008 https://doi.org/10.3366/E0264287509000267

[6] Kermode, F. (1976) Poet and Dancer before Diaghilev. Salmagundi, No. 33-34, 23-47.

[7] Mayer, C.S. (1977) The Influence of Leon Bakst on Choreography. Dance Chronicle, 1, 127-142. http://www.jstor.org/stable/1567428 https://doi.org/10.1080/01472527708568711

[8] Nelson, K. (1984) Bringing Fokine to Light. Dance Research Journal, 16, 3-12. https://doi.org/10.2307/1478716

[9] Fiero, G.K. (2014) The Humanistic Tradition 3 from the Nineteenth Century Onward. McGraw-Hill Education, Singapore, Foreign Language Teaching and Research Press, Beijing, 188.

[10] Antokoletz, E. (1986) Interval Cycles in Stravinsky's Early Ballets. Journal of the American Musicological Society, 39, 578-614.

https://doi.org/10.1525/jams.1986.39.3.03a00050 
[11] Liu, Q.-Y. (2004) Research on Dancology Fundamental Theory-Super Body of National Formulating Education. Journal of Beijing Dance Academy, 1, 5-14.

[12] Borny, G. (2006) Chekhov's Vision of Reality. In: Interpreting Chekhov, ANU Press, Canberra, 21-56. http://www.jstor.org/stable/j.ctt2jbjpn.6 https://doi.org/10.26530/OAPEN_459296

[13] Zhu, L. (2001) History of Western Ballet. Shanghai Music Publishing House, Shanghai, $42-44$

[14] Sturrock, J. (1981) Structuralism and Since: From Lévi-Strauss to Derrida. Oxford University Press, Oxford. https://doi.org/10.3817/0681048213

[15] Karlinsky, S. (2013) A Cultural Educator of Genius. Freedom from Violence and Lies, Essays on Russian Poetry and Music. Academic Studies Press, Boston, 465. https://doi.org/10.2307/j.ctt1zxsk34

[16] Wright, C. (2014) Listening to Music. 7th Edition, Clark Baxter, Boston, 263.

[17] Taylor, E. (1991) The AB Guide to Music Theory Part II. ABRSM Ltd., London, 242-247.

[18] Winestein, A. (2008) Quiet Revolutionaries: The "Mir Iskusstva" Movement and Russian Design. Journal of Design History, 21, 315-333. https://doi.org/10.1093/jdh/epn035

[19] Malmstad, J.E. (2011) Sergei Diaghilev “The Russian": Reflections on the Repertory of the Ballets Russes. Experiment, 17, 57. https://doi.org/10.1163/221173011X611824

[20] Wagner, R. (1966) The Art-Work of the Future. Richard Wagner's Prose Works Vol. 1, Trans. William Ashton Ellis, Broude Bros, New York.

[21] Zhang, Y. (2016) Western Dance Ar Seen under Western Culture History Perspective. Guangxi Normal University Press, Guilin, 108.

[22] Lieven, P.P. (1973) The Birth of the Ballets-Russes. Dover Publication, New York, 65.

[23] Engel, B.A. and Martin, J. (2015) Russia in World History. Oxford University Press, New York, 82-88.

[24] Jiang, H. (2016) Diaghilev and Britain Intellectual World. Russian Arts and Literature, No. 3, 130.

[25] Wang, M. (2012) Modernity: A Concept. Nanjing University Press, Nanjing, 2, 6, 27. 